\title{
Intraovarian actions of oestrogen
}

\author{
Cheryl S. Rosenfeld ${ }^{1}$, Jessica S. Wagner ${ }^{2}$, R. Michael Roberts $1,3,4$ \\ and Dennis B. Lubahn'1,2,3,5 \\ Departments of ${ }^{1}$ Animal Sciences, ${ }^{2}$ Molecular Biology Program, ${ }^{3}$ Biochemistry, ${ }^{4}$ Veterinary \\ Pathobiology, ${ }^{5}$ Child Health, University of Missouri, Columbia, MO 65211, USA
}

\begin{abstract}
Oestrogen regulates several hypothalamic and pituitary hormones, which in turn control ovarian functions. Oestrogen and its metabolites, such as catecholoestrogens, also have direct effects within the ovary. This review examines the roles of oestrogen in regulating ovarian folliculogenesis, ovulation and corpus luteum formation. Oestrogen promotes follicular development, which culminates in ovulation, by potentiating follicular development, granulosa cell expression of gonadotrophin receptors, steroidogenesis, and gap junction formation by granulosa cells, and by inhibiting granulosa cell apoptosis. In addition, oestrogen may be needed for corpus luteum formation and maintenance. Studies on mutant mice that either lack one or both of the known oestrogen receptors or are unable to synthesize oestrogen support some but not all of these prior inferences of the roles of oestrogen within the ovary. Although these transgenic mice have proved useful in determining some of the intraovarian actions of oestrogen, they present confounding problems, including hormonal imbalances, that hinder interpretation. Transgenic mice with conditional or tissue-directed mutations in their oestrogen receptors are needed to dissect the ovarian actions of oestrogen further. In addition, microarray technologies, combined with specific hormone treatment regimens are likely to provide an attractive, alternative approach to using mutant mice in clarifying the direct actions of oestrogen in the ovaries of other species.
\end{abstract}

Since the discovery of oestrogens in the early 1920s (Allen and Doisy, 1923), their effects have intrigued reproductive biologists. Classically, two approaches have been used to study the role of oestrogen within the ovary: surgical removal of the pituitary gland to eliminate confounding gonadotrophins, and pharmacological blockage of either the synthesis of oestrogen or its receptors both in vivo and in vitro. Although some studies have implicated a role for oestrogen within the ovary (Goldenberg et al., 1972; Nakayama et al., 1981; Nakano et al., 1982; Gore-Langton and Daniel, 1990; Nayudu and Osborn, 1992; Hulshof et al., 1995), others have not (Coney et al., 1987; Spears et al., 1998). Transgenic gene knockout technology has been used to investigate the intraovarian effects of oestrogen. Mice that lack either the P450aromatase gene (Fisher et al., 1998; Honda et al., 1998) or one or both of the known oestrogen receptors have been produced (Lubahn et al., 1993; Krege et al., 1998; Couse et al., 1999; Dupont et al., 2000; for review, see Rosenfeld et al., 2001). The main ovarian events studied for oestrogen involvement have been folliculogenesis, steroidogenesis, ovulation and corpus luteum formation.

Email: RosenfeldC@missouri.edu

\section{Oestrogen synthesis, sites of action and metabolism}

Androgens are produced by the thecal cells and, in general, they are taken up by the granulosa cells and converted by P450aromatase to various oestrogens with the main one being oestradiol (Fig. 1). In some species, such as pigs (Lautincik et al., 1994; Shores and Hunter, 1999), chickens (Kato et al., 1995) and tree shrews (Kimura et al., 2000), the thecal cells can also synthesize oestrogen. This steriod hormone is then released into the vasculature and circulated to the uterus, hypothalamus, mammary gland and various other reproductive and non-reproductive organs. Oestrogens may also exert local effects within the ovary. Some oestrogens appear also to be metabolized into presumed inactive as well as active products, such as the catecholoestrogens (Zhu and Conney, 1998; Fig. 1).

\section{Catecholoestrogens}

The enzymes, 2-hydroxylase (cyp1a1) and 4-hydroxylase (cyp1b1) catalyse the formation of catecholoestrogens from oestradiol (Fig. 1). Both of these catecholoestrogens can bind to the two known oestrogen receptors, ER $\alpha$ and ER $\beta$ (Kuiper et al., 1997). In addition, it has been proposed that they bind to a novel oestrogen receptor (Das et al., 1997) and possibly 




Fig. 1. Synthesis of oestradiol and catecholoestrogens. Testosterone is converted by P450aromatase into oestrogen (oestradiol). Oestradiol can then be metabolized into inactive and active metabolites, such as 2-hydroxyoestradiol and 4-hydroxyoestradiol. The enzymes 2hydroxylase and 4-hydroxylase catalyse the conversion of oestradiol to 2-hydroxyoestradiol and 4-hydroxyoestradiol, respectively. All of these enzymes are expressed by the granulosa cells.

even androgen receptor (Hudson and Hillier, 1985). Pig and human ovaries contain high concentrations of 2hydroxylase and 4-hydroxylase (Hammond et al., 1986; Muskhelishvili et al., 2001), and certain ovarian responses appear to be induced directly by these steroid metabolites, as discussed further below. The pattern of expression of these enzymes has not been examined throughout the oestrous cycle.

\section{Oestrogen receptors}

Oestrogen was the first steroid hormone demonstrated to activate transcription by binding to a receptor, the oestrogen receptor (for review, see Jensen and DeSombre, 1973). The receptors with their bound hormone modulate transcription by binding to oestrogen response elements (ERE) present on oestrogen-inducible genes (Kumar et al., 1987). The receptors can also act as co-regulators through binding to other transcription factors already attached to gene regulatory regions (Adler et al., 1988; Feng et al., 1998), and by ligand-independent mechanisms (IgnarTrowbridge et al., 1992). Although it was first believed that oestrogen receptors were predominantly cytoplasmic, it was later proposed that they are located exclusively within the nucleus (Welshons et al., 1984; Greene et al., 1986). It is now clear that these receptors can be found in both the cytoplasm and nucleus, with the ratio dependent upon the cell type and physiological conditions (Yamashita, 1998; Zieba et al., 2000). Some studies also indicate that oestrogen receptors reside on the plasma membrane and modulate cellular activity without directly associating with DNA (Morley et al., 1992; Levin, 1999; Pietras and Szego, 1999; Nadal et al., 2000).
The oestrogen receptors are members of the superfamily of steroid nuclear receptors (Parker, 1995; Baker, 1997; White and Parker, 1998). All steroid receptors have a DNAbinding domain that is composed of two zinc fingers followed by a C-terminal ligand-binding domain (Parker, 1995; White and Parker, 1998). Currently, two oestrogen receptors, ER $\alpha$ (Green et al., 1986; Greene et al., 1986) and ERß (Kuiper et al., 1996; Mosselman et al., 1996) have been cloned. These two receptors have considerable sequence identity in the DNA-binding domains, which permit both receptor types to interact with EREs of various genes. Sequence differences between the two receptors occur primarily in the $\mathrm{N}$ - and C-terminal regions (Kuiper et al., 1996; Mosselman et al., 1996).

There are many alternatively spliced forms of both ER $\alpha$ and ER $\beta$ (Chu and Fuller, 1997; Petersen et al., 1997; Kos et al., 2000; Poola et al., 2000). The alternatively spliced forms of $E R \alpha$ have been identified predominantly in human breast cancer and other tumour cell lines (Kos et al., 2000; Poola et al., 2000) but not in normal ovarian cells. One alternative form of ER $\beta$ identified in rats lacks exon 4, which forms the second zinc finger of the DNA-binding domain, whereas another form has 18 additional codons in the ligandbinding domain, which results in a protein with only $10 \%$ of the oestradiol-binding affinity and 100- to 1000-fold lower transcriptional activation potential compared with the full length receptor (Petersen et al., 1997). This form with 18 additional amino acids appears to be the predominant $E R \beta$ in various mouse organs, including the ovary (Lu et al., 2000). A third form of ER $\beta$ described in rats carries a deletion of the second zinc finger, as well as the 18 additional codons in the ligand-binding domain (Petersen et al., 1997) (Fig. 2). All three of these aforementioned forms have been identified in 


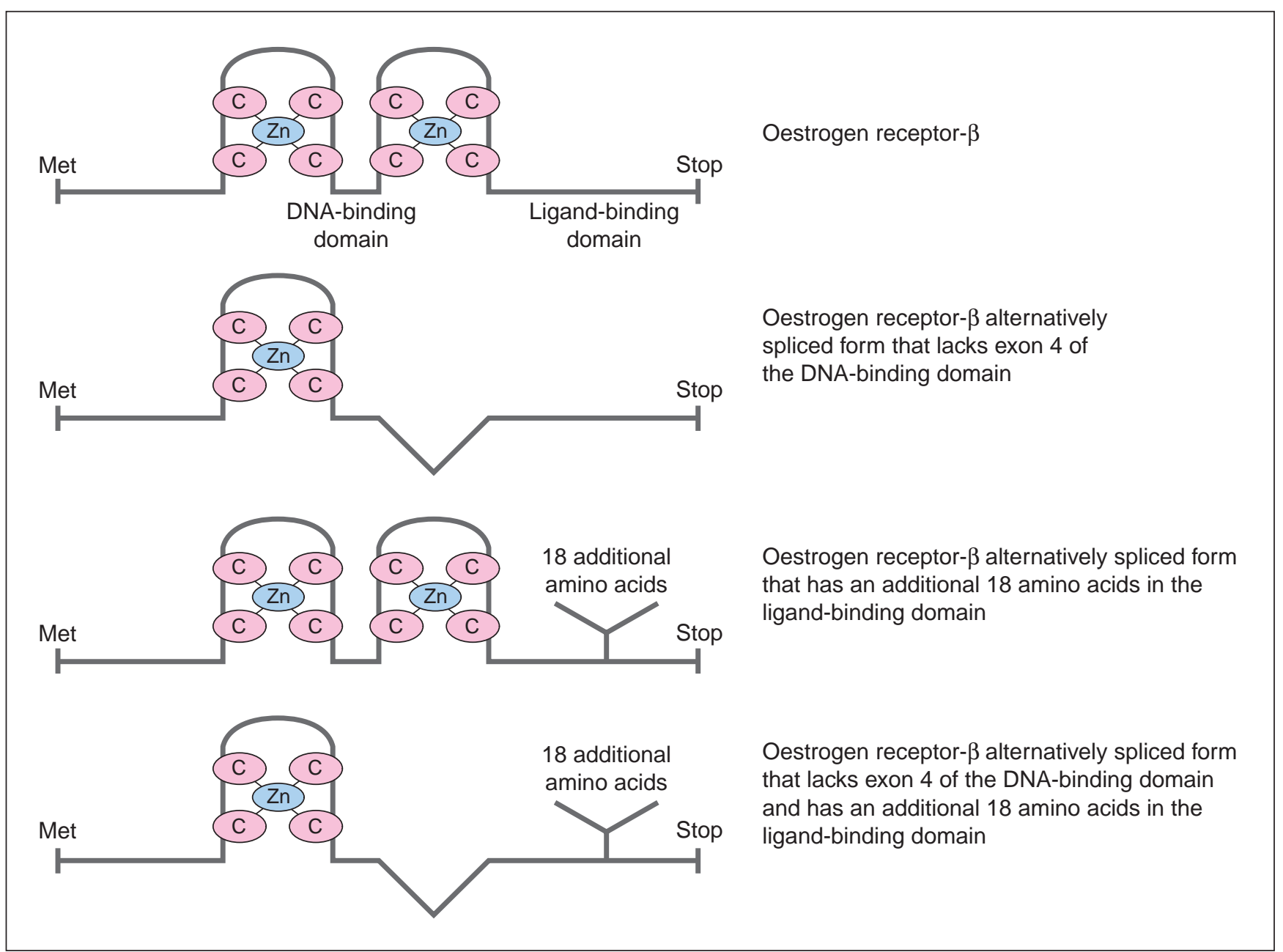

Fig. 2. Alternatively spliced forms of oestrogen receptor $\beta(E R \beta)$ identified in the rat ovary. Spliced forms that have a deletion of the second finger, which contributes to binding of the oestrogen responsive element on DNA, are presumably unable to induce transcription through the oestrogen response element. Other forms that have insertion of amino acids within the ligand-binding domain may have different binding affinities to the various endogenous oestrogens.

the rat ovary (Petersen et al., 1997), and thus, each may regulate oestrogenic activity in the rodent ovary. In addition, other novel human ER $\beta$ forms, which differ in their Cterminal sequences, have been identified, and some of these are expressed in the human ovary (Moore et al., 1998).

The discovery of ER $\beta$ raises the question as to whether mammals possess additional oestrogen receptors that have yet to be identified. No such genes have been identified to date in the human genome, although there is some evidence for at least one additional oestrogen receptor in the mouse ovary and uterus (Kudolo et al., 1984a,b; Hillier et al., 1989; Das et al., 1997; Ghosh et al., 1999; for review, see Rosenfeld et al., 2001). Moreover, a third oestrogen receptor, ER $\gamma$, has been identified in fish (Hawkins et al., 2000). ER $\gamma$ is distinct from other fish ER $\alpha$ s and ERßs, but is quite closely related to ER $\beta$. In mammals, alternatively spliced forms of ER $\alpha$ and ER $\beta$ that differ in their ligandbinding domains may represent novel oestrogen receptors because these mutations might alter their ability to interact with various endogenous oestrogens, their metabolites and antagonists.

For oestrogens to act on specific cell types in the ovary, ovarian oestrogen receptors must be present, and oestrogeninduced gene activation generally occurs. The ovarian cell types in which $E R \alpha$ and $E R \beta$ have been identified are listed (Table 1). In all species studied to date, ER $\beta$ is the most abundant ovarian oestrogen receptor. This receptor is especially prominent in granulosa cells, but it is also expressed in luteal cells and, to a lesser extent, in thecal cells (see references in Table 1 ).

\section{Regulation of ovarian oestrogen receptor expression}

As in other oestrogen-responsive organs, such as the uterus, oestrogen downregulates granulosa cell expression of ERß protein (Sharma et al., 1999). In rodents, treatment 





with gonadotrophins, in particular $\mathrm{LH}$, results in a marked decrease of ER $\beta$ in the ovary (Byers et al., 1997; Fitzpatrick et al., 1999). This effect is mediated through a CAMPdependent pathway. Not surprisingly, addition of cAMP to cultured rat granulosa cells also decreases ER $\beta$ expression (O'Brien et al., 1999). In contrast, when cattle are infused with ovulatory dosages of LH, ovarian ER $\beta$ concentrations are not altered (Manikkam et al., 1999). Why this species difference occurs is not clear, but it may relate to the manner in which follicular maturation and selection occurs in the two species, that is, polyovulatory rodents versus generally monovulatory cattle. ER $\beta$ may regulate early follicular growth in rodents, whereas it may exert control over both early and late follicular development in cattle.

Mice that lack $\mathrm{LH}-\mathrm{hCG}$ receptors have a marked decrease in ovarian $\mathrm{ER} \alpha \mathrm{mRNA}$, but an increase in ovarian ER $\beta$ mRNA expression, as determined by northern blot analysis (Lei et al., 2001). Oestrogen and progesterone treatment of these mice restores $E R \alpha$ mRNA to the amounts found in wild-type mice, but ER $\beta$ mRNA remains increased. These findings support the contention that $\mathrm{LH}$ signalling is needed in mice to maintain proper ovarian ER $\beta$ mRNA concentrations. Concomitantly, the absence of $E R \alpha$ results in increased serum concentrations of LH (Rissman et al., 1997; Couse and Korach, 1999), and thus, ER $\alpha$ is needed to maintain normal LH concentrations.

\section{Intraovarian effects of oestrogen}

\section{Folliculogenesis}

As the ovarian follicles grow and differentiate, increasing amounts of oestrogen are produced (Fortune, 1994), which, in turn, upregulate the synthesis and release of the pituitary gonadotrophins, $\mathrm{FSH}$ and $\mathrm{LH}$, thereby promoting ovarian follicular growth. On the basis of some reports, oestrogen directly increases the number and size of ovarian follicles in vivo and the size of rat, mouse and bovine follicles in culture (Goldenberg et al., 1972; Nakayama et al., 1981; Nakano et al., 1982; Gore-Langton and Daniel, 1990; Nayudu and Osborn, 1992; Hulshof et al., 1995). However, other studies on rat and ovarian follicles have not supported this finding (Coney et al., 1987; Spears et al., 1998).

If oestrogen is indeed directly promoting ovarian follicular growth, it is uncertain which oestrogen receptors are involved. Both the $\mathrm{ER} \alpha$ knockout (ER $\alpha \mathrm{KO}$ ) (Rosenfeld et al., 2000) and ERßKO (Krege et al., 1998) mice exhibit follicular development to the Graafian stage, albeit to a lesser extent than in wild-type sibling mice. However, ER $\alpha \beta$ double $\mathrm{KO}$ mice are infertile because of follicular arrest (Couse et al., 1999; Dupont et al., 2000). Nevertheless, early follicular growth and development occurs in these mice, even though mature Graafian follicles do not form. Collectively, these results indicate that, in mice, $\mathrm{ER} \alpha$ or $\mathrm{ER} \beta$ can compensate, at least partially, for the absence of the other to provide mature ovulatory follicles, but may not be necessary for the earlier stages of follicular growth.
Aromatase knockout (ArKO) mice can complete folliculogenesis without exogenous oestrogens, but the process is impaired, with fewer follicles reaching maturity than in wild-type controls (Fisher et al., 1998; Britt et al., 2000). ArKO mice that are treated with oestradiol every 4 days from 4 weeks of age for 1 month have increased numbers of follicles compared with untreated ArKO mice. However, these treated mice still do not develop corpora lutea (Toda et al., in press). On the basis of these data, folliculogenesis can occur, albeit sub-normally, in the absence of either oestrogen or one of its two known receptors.

\section{Gonadotrophin receptor expression}

Growing follicles express gonadotrophin receptors. Before selection, follicles express FSH receptors, but LH receptors emerge later in the dominant follicles. In cattle, when the dominant follicles are first selected, FSH reaches its nadir (Fortune, 1994) while serum concentrations of $\mathrm{LH}$ begin to increase. It is presumed that only those follicles that express $\mathrm{LH}$ receptors in granulosa cells can be rescued and, in time, ovulated.

Oestrogen increases follicular expression of both $\mathrm{FSH}$ and $\mathrm{LH}$ receptors in rat granulosa cells (Richards et al., 1976, 1979). Those follicles that first begin to produce significant amounts of oestrogen are more likely to possess more gonadotrophin receptors. Therefore, whether or not a particular follicle expresses oestrogen receptors may control its fate. However, ER $\alpha$ KO mice have increased expression of granulosa and thecal LH receptor (Schomberg et al., 1999), again indicating a lack of $E R \alpha$ involvement in control of follicular growth. These mice also have increased serum oestrogen concentrations, which may increase granulosa cell expression of $\mathrm{LH}$ receptor by acting through $\mathrm{ER} \beta$ or one of the putative additional receptor types. There is currently no information on the ovarian expression of $\mathrm{FSH}$ and $\mathrm{LH}$ receptors in $\mathrm{ER} \beta \mathrm{KO}$ and $\mathrm{ER} \alpha \beta$ double $\mathrm{KO}$ mice. If oestrogen acts through ER $\beta$ to upregulate gonadotrophin receptor expression, ER $\beta$ mutant mice presumably would have decreased expression of FSH and LH receptors.

\section{Steroid production}

Ovarian steroid hormones are produced throughout the oestrous cycle. During folliculogenesis, the thecal cells produce androgens, which are converted into oestrogens by P450aromatase in the granulosa cells. Both oestradiol (Fortune and Hansel, 1979; Leung and Armstrong, 1980; Welsh et al., 1983; Roberts and Skinner, 1990) and catecholoestrogens (Spicer and Hammond, 1987; Tekpetey and Armstrong, 1994) can regulate the production of androgen and progesterone within bovine, rat and pig ovaries. Oestrogen is known to increase CYP17 expression by rat theca cells (Johnson and Crane, 1995). The oestrogen-driven increase in progesterone presumably promotes corpus luteum formation and maintenance through luteal progesterone receptors (Duffy and Stouffer, 1995; Smith et al., 1995). 
Promotes folliculogenesis

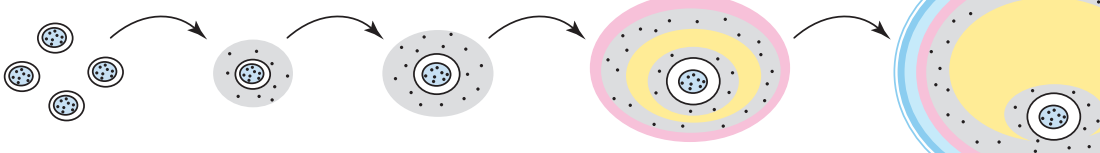

Increases expression of gonadotrophin receptors by granulosa cells

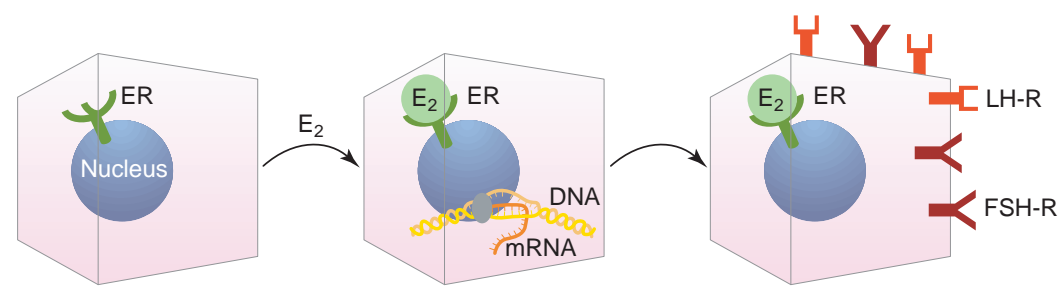

Increases gap junction formation by granulosa cells

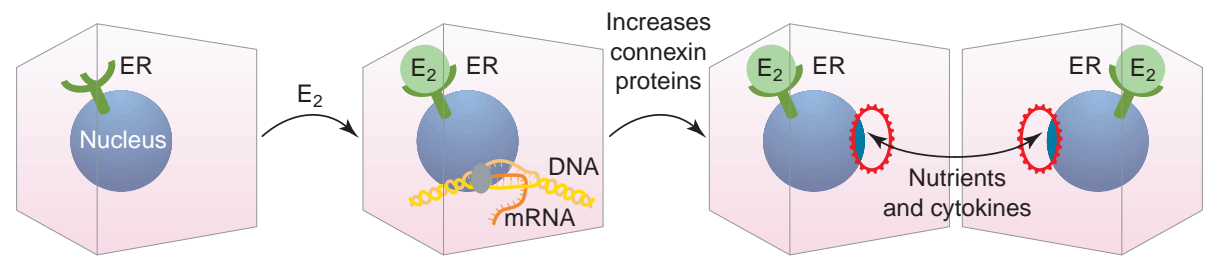

Increases steroid synthesis


Inhibits granulosa cell apoptosis

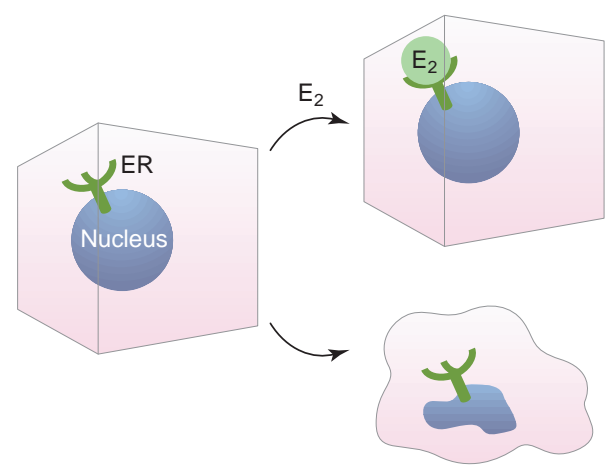




\section{Gap junctions}

As the follicles continue to grow and proliferate, the avascular granulosa cell lining becomes removed from the nutrient-providing interstitial blood vessels. Gap junctions permit transfer of nutrients and cytokines to and from the granulosa cells and developing oocytes (Albertini and Anderson, 1974; Anderson and Albertini, 1976). Oestrogen controls granulosa cell gap junction formation (Merk et al., 1972; Burghardt and Anderson, 1981). Gap junctions are composed of various connexin proteins: connexin 43 is a major granulosa and luteal gap junction protein in bovine (Nuttinck et al., 2000), ovine (Grazul-Bilska et al., 1998), pig (Lenhart et al., 1998) and rat (Mayerhofer and Garfield, 1995) ovaries, and is oestrogen-regulated (Yu et al., 1994). One method whereby oestrogen might potentiate gap junction formation between granulosa cells is through induction of this protein. However, connexin 43 protein expression has not been reported in any of the oestrogen receptor or P450arom mutant female mice.

\section{Apoptosis}

Most follicles do not reach the ovulatory stage but instead become atretic owing to apoptosis of the granulosa cell lining (Kaipia and Hsueh, 1997; Amsterdam et al., 1999). This process is normally tightly regulated with anti- and proapoptotic factors balancing each other, and with crosstalk among multiple intracellular pathways determining the final outcome of the cell (Kaipia and Hsueh, 1997; Amsterdam et al., 1999). Oestrogen inhibits granulosa cell apoptosis (Billig et al., 1993). In contrast, androgens promote apoptosis (Billig et al., 1993).

As with other ovarian processes, it is uncertain which oestrogen receptors are mediating this oestrogenic antiapoptotic effect. In addition, it is not clear whether there are physiological repercussions if the anti-apoptotic mechanism is perturbed. In 10-12-week-old ArKO mice, many apoptotic granulosa cells are present in large antral follicles (Britt et al., 2000), and by 21-23 weeks of age, these mice have fewer antral follicles than do wild-type controls. Predictably, ArKO mice have increased ovarian expression of pro-apoptotic genes, such as p53 and Bax, compared with wild-type mice (Toda et al., in press). At 1 year of age, the ArKO mice have a reduced number of primary follicles, all of which contain numerous apoptotic cells (Britt et al., 2000). By contrast, ER $\alpha \mathrm{KO}$ mice have similar numbers of apoptotic granulosa cells when compared with wild-type control mice (Schomberg et al., 1999). Although oestrogen may be essential for preventing the demise of ovarian follicles, this protection is clearly not conferred through $\mathrm{ER} \alpha$.

\section{Corpus luteum formation and maintenance}

Early studies with hypophysectomized or X-irradiated rabbits and rats with hypothalamic lesions indicated that oestrogen directly regulates corpus luteum formation and controls luteal maintenance (Robson, 1937; Bogdanove, 1966; Keyes and Nalbandov, 1967). Unexpectedly, ERßKO mice demonstrate normal corpus luteum development, but have an overall reduced fertility (Krege et al., 1998). Prepubertal ER $\alpha \mathrm{KO}$ mice treated with superovulatory dosages of gonadotrophins also develop steroidogenically functional corpora lutea, but they remain infertile (Rosenfeld et al., 2000). Thus, the phenotypes of these mutant mice do not corroborate earlier studies. In contrast, ArKO and $E R \alpha \beta$ double $\mathrm{KO}$ mice do not undergo luteinization and corpus luteum formation (Fisher et al., 1998; Couse et al., 1999; Britt et al., 2000; Dupont et al., 2000). Taken together, these findings indicate that oestrogen is indeed needed for corpus luteum formation and maintenance, and that it likely acts non-selectively through $\mathrm{ER} \alpha$ or $\mathrm{ER} \beta$ with one oestrogen receptor compensating for the absence of the other. If both receptors are lacking, oestrogen cannot stimulate luteinization.

\section{Non-genomic actions of oestrogen within the ovary}

The complex physiological responses to oestrogen are generally presumed to involve transcriptional regulation of many genes. However, oestrogen-binding to putative membrane oestrogen receptors (Levin, 1999) may also induce non-genomic-non-transcriptionally mediated responses. In cultured granulosa cells, oestrogen has been implicated in causing a rapid increase in intracellular $\mathrm{Ca}^{2+}$ concentrations (Morley et al., 1992). As this response occurs within seconds of treating the cells with oestrogen, a reasonable conclusion is that it is occurring without transcriptional activation, that is, it is elicited through some existing membrane-associated response. The demonstration that $\mathrm{ER} \alpha$ associates with the regulatory subunit of phosphatidylinositol-3-OH kinase $(\mathrm{PI}(3) \mathrm{K})$ in the presence of ligand may provide at least a partial explanation for the non-genomic effects of oestrogen (Simoncini et al., 2000), and thus provide another dimension to oestrogenic action within the ovary. Non-genomic responses have not yet been studied in transgenic mice.

\section{Confounding problems in interpreting ovarian phenotypes in oestrogen- and oestrogen receptor- deficient mice}

Although these knockout mice have proved invaluable in elucidating some of the roles of oestrogen within the ovary,

Fig. 3. Illustration of the proposed intraovarian actions of oestrogen. On the basis of past pharmacological, surgical, and culture approaches, oestrogen modulates many ovarian responses, including promoting folliculogenesis, increasing granulosa cell gonadotrophin receptor expression, increasing gap junction formation between granulosa cells, increasing steroid production by both thecal and luteal cells, and inhibiting granulosa cell apoptosis. $\mathrm{E}_{2}$ : oestrogen; LH-R: LH receptor, FSH-R: FSH receptor. 
confounding factors hinder interpretation of the resulting ovarian phenotypes. In rodents, only one P450aromatase gene has been identified and knocked out (Youngblood et al., 1989; Fisher et al., 1998; Honda et al., 1998). However, such mice are likely to have been exposed in utero to maternal oestrogen and postnatally to other sources of oestrogen, including compounds in the environment and diet, which would hinder interpreting the reproductive phenotypes of the adult animals. Furthermore, it is now apparent that there are non-aromatized steroid molecules, such as hermaphrodiol, that have both androgenic and oestrogenic activity (Lima et al., 2000; Rosenberg-Zand et al., 2000). Therefore, proper interpretation of ovarian phenotypes in ArKO mice requires exclusion of all sources of both aromatic and non-aromatic oestrogenic molecules. In addition, ArKO mice have secondary hormonal imbalances, such as increased serum concentrations of $\mathrm{LH}$, FSH and androgen, which may account for some of the ovarian pathology (Fisher et al., 1998).

The ERKO mice also have secondary hormonal imbalances, including an increase in serum $\mathrm{LH}$, which is present in both ERoKO (Rissman et al., 1997; Couse and Korach, 1999) and ER $\alpha \beta$ double KO (Couse et al., 1999a) mice. In ERKO mice, all receptors that bind oestrogen have to be considered and deleted before it is possible to make accurate inferences about which oestrogen receptors mediate the intraovarian effects of oestrogen. Novel oestrogen receptors may be discovered once the mouse and human genomic sequences are fully annotated and the properties of forms arising by alternative splicing elucidated. It is interesting to note that the orphan oestrogen-related receptors $(E R R \alpha, \beta$, and $\gamma$ ), the endogenous ligands of which are unknown, have been demonstrated, albeit with low affinity, to bind diethylstilboestrol (DES) but not oestradiol (Tremblay et al., 2001). Thus, the ERRs may play a role in oestrogenic actions within the ovary, although as yet these receptors have not been examined fully in the ovary.

Ultimate resolution of these difficulties may depend on the creation of more sophisticated approaches to producing mutant mice that have ovarian cell-specific and conditional ablation of oestrogen receptors. Production of such mice would permit a thorough analysis of the effects of oestrogen-binding to oestrogen receptors throughout the oestrous cycle and pregnancy and would have minimal confounding hormonal imbalances. Transgenic mice with tamoxifen-dependent Cre recombinase fused to a mutated ligand-binding domain of human oestrogen receptor have been produced (Metzger and Chambon, 2001) and, when these mice are treated with tamoxifen, the chromosomally integrated gene, which is flanked by loxP sites, is excised.

\section{Studying the intraovarian actions of oestrogen in other species}

It is worth considering whether the mouse is the best model with which to study the intraovarian effects of oestrogen. Is it possible, for example, to extrapolate from responses seen in rodents to other species? Although women, cows and mares are generally monovulatory, rodents are polyovulatory, and thus, the regulation of folliculogenesis may be different. How then can the in vivo effects of oestrogen in the ovaries of other species be studied, where the targeted deletion of genes is not currently possible? Microarray technology could be invaluable in this respect and provide comparison of oestrogen-regulated genes in various ovarian cells during puberty, the oestrous cycle, pregnancy and in response to oestrogenic treatment. This technique could be used in combination with pharmacological blockage of one or more oestrogen receptors to provide multiple snapshots of the intraovarian effects of oestrogen. An ovarian gene database (http://ovary.stanford.edu; Melner and Korach, 2000) has been established that may assist in the identification of all the oestrogen-regulated ovarian genes.

\section{Regulation of oestrogen action within the ovary}

Although there is ample evidence that oestrogen acts within the ovary, it also originates there, and is present in highest concentrations in this organ. Such quantities would in theory continually saturate and activate any cognate receptors, and potentially result in either continual transcriptional activation or other consequences such as desensitization. Some regulation of this system must occur to prevent such scenarios. One regulatory step could be at the receptor level. Oestrogen receptors may be required for only a limited period of follicular development but persist thereafter in a subfunctional state.

Co-activators may provide another level of regulation. These factors act in concert with oestrogen receptors to induce transcription of oestrogen-responsive genes. Various transcription factors, such as SRC-1, GRIP1, RAC3, p300, SPA AIB1, RIP140, SMRT, Fas-associated protein-tyrosine phophatase-1 (FAP-1), and co-activator independent of AF-2 function $(\mathrm{ClA})$ that regulate oestrogen-responsive genes have been identified (Rey et al., 2000; Hlaing et al., 2001; Sauve et al., 2001). Possibly, it is their specific expression pattern and not that of the cognate receptors that governs the oestrogen responsiveness of granulosa and other ovarian cells. Differential expression of some of the oestrogen receptor co-activators supports this hypothesis (Hlaing et al., 2001). Although granulosa, thecal and stromal cells in ovine ovaries express SRC-1, RIP140 and SPA mRNA, granulosa cells have the highest mRNA expression for these coactivators (Hlaing et al., 2001). Similarly, the ovine corpus luteum expresses smaller amounts of SRC-1 and RIP1240 mRNA than do follicular cells (Hlaing et al., 2001).

A third form of regulation may be through metabolism of oestrogen by the cyp enzymes into various active and inactive metabolites. Compounds, such as the catecholoestrogens, may bind oestrogen receptors (Kuiper et al., 1997), androgen receptor (Hudson and Hillier, 1985) and other novel steroid receptors (Das et al., 1997, 2000), resulting in responses both quantitatively and qualitatively distinct from the parental steroid. How efficiently the various ovarian cells convert 
oestradiol into these metabolites might provide another level of control.

In summary, selective expression of oestrogen receptors, co-activational factors, and metabolic conversion of oestradiol may regulate the intraovarian effects of oestrogen. Similar processes could be invoked in other tissues in which a hormone acts within its originating tissue. For example, progesterone receptors are found in the bovine and primate corpus luteum (Smith et al., 1995; Duffy and Stouffer, 1995).

\section{Conclusions}

The intraovarian effects of oestrogen have been examined. Early work indicated that oestrogen directly regulates ovarian folliculogenesis, corpus luteum formation, granulosa cell expression of the gonadotrophin receptors, gap junction formation between granulosa cells, granulosa cell apoptosis and steroid production by granulosa, thecal and luteal cells (Fig. 3). These actions are presumably regulated by specific oestrogen receptors. ER $\beta$ is the predominant form of oestrogen receptor found in the ovary (Byers et al., 1997; Couse et al., 1997).

Aromatase-deficient and oestrogen receptor-deficient mice have been created to study the effects of oestrogen. Although results from these mice support a role for oestrogen in the ovary, some of the data are equivocal, such that the phenotypes cannot always be directly attributed to the absence of the gene, since secondary hormonal imbalances and other confounding factors invariably occur in these mice. More sophisticated, tissue-targeted knockout mice are needed to elucidate the roles of oestrogen within the ovary. The involvement of oestrogen in ovarian physiology needs to be examined in several species before any firm and general conclusions can be drawn about its intraovarian effects.

The authors wish to thank Alison Murray, Norah Spears, Michael F. Smith, Mohan Manikkam, Michele Calder, H. Allen Garverick, and members of Dennis Lubahn's and R. Michael Roberts' laboratories for their assistance. These studies were supported by the following grants: NIH ES 08272 (D. B. Lubahn), Army DAMD 17-97-1-7171 (D. B. Lubahn), EPA R825295 (D. B. Lubahn), and a USDA National Needs Fellowship (to C. S. Rosenfeld).

\section{References}

Key references are identified by asterisks.

Adler S, Waterman ML, He X and Rosenfeld MG (1988) Steroid receptormediated inhibition of rat prolactin gene expression does not require the receptor DNA-binding domain Cell 52 685-695

Albertini DF and Anderson E (1974) The appearance and structure of intercellular connections during the ontogeny of the rabbit ovarian follicle with particular reference to gap junctions Journal of Cell Biology $63234-250$

Allen E and Doisy EA (1923) An ovarian hormone. Preliminary report on its localization, extraction, and purification, and action in test animals Journal of the American Medical Association 81 819-821

Amsterdam A, Gold RS, Hosokawa K, Yoshida Y, Sasson R, Jung YS and
Kotsuji F (1999) Crosstalk among multiple signaling pathways controlling ovarian cell death Trends in Endocrinology and Metabolism 10 255-262

Anderson E and Albertini DF (1976) Gap junctions between the oocytes and companion follicle cells in the mammalian ovary Journal of Cell Biology 71 680-686

Baker ME (1997) Steroid receptor phylogeny and vertebrate origins Molecular Cellular Endocrinology 135 101-107

Billig H, Furuta I and Hsueh AJW (1993) Estrogens inhibit and androgens enhance ovarian granulosa cell apoptosis Endocrinology 133 2204-2212

Bogdanove EM (1966) Preservation of functional corpora lutea in the rat by estrogen treatment Endocrinology 79 1011-1015

*Britt KL, Drummond AE, Cox VA, Dyson M, Wreford NG, Jones MEE, Simpson ER and Findlay JK (2000) An age-related ovarian phenotype in mice with targeted disruption of the Cyp 19 (Aromatase) gene Endocrinology $1412614-2623$

Burghardt RC and Anderson E (1981) Hormonal modulation of gap junctions in rat ovarian follicles Cell Tissue Research 214 181-193

Byers M, Kuiper GGJM, Gustafsson J-A and Park-Sarge O-K (1997) Estrogen receptor- $\beta$ mRNA expression in rat ovary: downregulation by gonadotropins Molecular Endocrinology 11 172-182

Chu S and Fuller PJ (1997) Identification of a splice variant of the rat estrogen receptor beta gene Molecular Cellular Endocrinology 132 195-199

Coney P, Yoshimura Y, Hosoi Y, Bongiovanni A and Wallach E (1987) Effect of aromatase inhibitors on the histology of cycling rat ovary Gynecological Obstetrics Investigations 23 177-183

Couse JF and Korach KS (1999) Estrogen receptor null mice: what have we learned and where will they lead us? Endocrine Reviews 20 358-417

Couse JF, Lindzey J, Grandien K, Gustafsson J-A and Korach KS (1997) Tissue distribution and quantitation analysis of estrogen receptor- $\alpha$ $(E R \alpha)$ and estrogen receptor- $\beta$ (ER $\beta$ ) messenger ribonucleic acid in the wild-type and ER- $\alpha$ knockout mouse Endocrinology 138 4613-4621

*Couse JF, Curtis-Hewitt S, Bunch DO, Sar M, Walker VR, Davis BJ and Korach KS (1999) Postnatal sex reversal of the ovaries in mice lacking estrogen receptors $\alpha$ and $\beta$ Science $\mathbf{2 8 6} 2328-2331$

*Das SK, Taylor JA, Korach KS, Paria BC, Dey SK and Lubahn DB (1997) Estrogenic responses in estrogen receptor- $\alpha$ deficient mice reveal a distinct estrogen signaling pathway Proceedings of the National Academy of Sciences USA 9412 786-12 791

Das SK, Tan J, Raja S, Halder J, Paria BC and Dey SK (2000) Estrogen targets genes involved in protein processing, calcium homeostasis, and Wnt signaling in the mouse uterus independent of estrogen receptor- $\alpha$ and $-\beta$ Journal of Biological Chemistry 27528 834-28 842

Duffy DM and Stouffer RL (1995) Progesterone receptor messenge ribonucleic acid in the primate corpus luteum during the menstrual cycle: possible regulation by progesterone Endocrinology 136 1869-1876

*Dupont S, Krust A, Gansmuller A, Dierich A, Chambon P and Mark M (2000) Effect of single and compound knockouts of estrogen receptors $\alpha$ $(E R \alpha)$ and $\beta(E R \beta)$ on mouse reproductive phenotypes Development 127 4277-4291

Feng W, Ribeiro RC, Wagner RL, Nguyen H, Apriletti JW, Fletterick RJ, Baxter JD, Kushner PJ and West BL (1998) Hormone-dependent coactivator binding to a hydrophobic cleft on nuclear receptors Science 280 1747-1749

*Fisher CR, Graves KH, Parlow AF and Simpson ER (1998) Characterization of mice deficient in aromatase (ArKO) because of targeted disruption of the cyp19 gene Proceedings of the National Academy of Sciences USA 95 6965-6970

Fitzpatrick SL, Funkhouser JM, Sindoni DM, Stevis PE, Deecher DC, Bapat AR, Merchenthaler I and Frail DE (1999) Expression of estrogen receptor-beta protein in rodent ovary Endocrinology 140 2581-2591

Fortune JE (1994) Ovarian follicular growth and development in mammals Biology of Reproduction 50 225-232

Fortune JE and Hansel W (1979) The effects of 17ß-estradiol on progesterone secretion by bovine theca and granulosa cells Endocrinology 104 1834-1838

Ghosh D, Taylor JA, Green JA and Lubahn DB (1999) Methoxychlor 
stimulates estrogen-responsive messenger ribonucleic acids in mouse uterus through a non-estrogen receptor (Non-ER) $\alpha$ and Non-ER $\beta$ mechanism Endocrinology $1403526-3533$

Goldenberg RL, Vaitukaitis JL and Ross GT (1972) Estrogen and folliclestimulating hormone interactions on follicle growth in rats Endocrinology 90 1492-1498

Gore-Langton RE and Daniel SAJ (1990) Follicle-stimulating hormone and estradiol regulate antrum-like reorganization of granulosa cells in rat preantral follicle cultures Biology of Reproduction 43 65-72

Grazul-Bilska AT, Redmer DA, Bilski JJ, Jablonka-Shariff A, Doraiswamy V and Reynolds LP (1998) Gap junctional proteins, connexin 26, 32, and 43 in sheep ovaries throughout the estrous cycle Endocrine 8 269-279

Green S, Walter P, Kumar V, Krust A, Bornert J-M, Argos P and Chambon P (1986) Human oestrogen receptor cDNA: sequence, expression, and homology to v-erb-A Nature 320 134-139

Greene GL, Gilna P, Waterfield M, Baker A, Hort Y and Shine J (1986) Sequence and expression of human estrogen receptor complementary DNA Science 231 1150-1154

Hammond JM, Hersey RM, Walega MA and Weisz J (1986) Catecholestrogen production by porcine ovarian cells Endocrinology 118 2292-2299

Hawkins MB, Thornton JW, Crews D, Skipper JK, Dotte A and Thomas P (2000) Identification of a third distinct estrogen receptor and reclassification of estrogen receptors in teleosts Proceedings of the National Academy of Sciences USA $9710751-10756$

Hillier SG, Saunders PTK, White R and Parker MG (1989) Oestrogen receptor mRNA and a related transcript in mouse ovaries Journal of Molecular Endocrinology 2 39-45

Hlaing M, Nam K, Lou J, Pope WF and Nephew KP (2001) Evidence for expression of estrogen receptor cofactor messenger ribonucleic acid in the ovary and uterus of domesticated animals (sheep, cow and pig) Life Sciences 68 1427-1438

Honda S, Harada N, Ito S, Takagi Y and Maeda S (1998) Disruption of sexual behavior in male aromatase-deficient mice lacking exons 1 and 2 of the cyp19 gene Biochemical Biophysical Research Communications 252 445-449

Hosokawa K, Ottander U, Wahlberg P, Ny T, Cajander S and Olofsson IJ (2001) Dominant expression and distribution of oestrogen receptor $\beta$ over oestrogen receptor $\alpha$ in the human corpus luteum Molecular Human Reproduction 7 137-145

Hudson KE and Hillier SG (1985) Catechol oestradiol control of FSHstimulated granulosa cell steroidogenesis Journal of Endocrinology $\mathbf{1 0 6}$ R1-R4

Hulshof SCJ, Figueiredo JR, Beckers JF, Beyers MM, van der Donk JA and van den Hurk R (1995) Effects of fetal bovine serum, FSH, and $17 \beta$ estradiol on the culture of bovine preantral follicles Theriogenology $\mathbf{4 4}$ 217-226

Ignar-Trowbridge DM, Nelson KG, Bidwell MC, Curtis SW, Washburn TF, McLachlan JA and Korach KS (1992) Coupling of dual signaling pathways: epidermal growth factor action involves the estrogen receptor Proceedings of the National Academy of Sciences USA $894658-4662$

Jensen EV and DeSombre ER (1973) Estrogen-receptor interaction Science $182126-134$

Johnson DC and Crane LH (1995) Inhibitory and stimulatory effects of oestrogens upon $17 \alpha$-hydroxylase/C17,20-lyase in immature hypophysectomized rats treated with gonadotrophin Journal of Endocrinology 145 59-67

Kaipia A and Hsueh AJW (1997) Regulation of ovarian follicular atresia Annual Review of Physiology 59 349-363

Kato M, Shimada K, Saito N, Noda K and Ohta M (1995) Expression of P450 $17 \alpha$-hydroxylase and P450aromatase genes in isolated granulosa, theca interna, and theca externa layers of chicken ovarian follicles during follicular growth Biology of Reproduction 52 405-410

Keyes PL and Nalbandov AV (1967) Maintenance and function of corpora lutea in rabbits depend on estrogen Endocrinology 80 938-946

Kimura J, Tsukise A, Watanabe G, Taya K, Rerkamnuaychoke W, Endo H, Kurohmaru M, Yamada J and Nishida T (2000) Immunohistochemical localization of inhibin and steroidogenic enzymes in ovary of common tree shrew (Tupaia glis) and northern smooth-tailed shrew (Dendrogale murina) Anatomical Histological Embryology 29 267-271
Kos M, O'Brien S, Flouriot G and Gannon F (2000) Tissue-specific expression of multiple mRNA variants of the mouse estrogen receptor $\alpha$ gene FEBS Letters $\mathbf{4 7 7}$ 15-20

*Krege JH, Hodgin JB, Couse JF, Enmark E, Warner M, Mahler JF, Sar M, Korach KS, Gustafsson J-A and Smithies O (1998) Generation and reproductive phenotypes of mice lacking estrogen receptor $\beta$ Proceedings of the National Academy of Sciences USA 95 15 677-15 682

Kudolo GB, Elder MG and Myatt L (1984a) A novel oestrogen-binding species in rat granulosa cells Journal of Endocrinology 102 83-91

Kudolo GB, Elder MG and Myatt L (1984b) Further characterization of the second oestrogen-binding species of the rat granulosa cell Journal of Endocrinology 102 93-102

*Kuiper GGJM, Enmark E, Pelto-Huikko M, Nilsson S and Gustafsson J-A (1996) Cloning of a novel estrogen receptor expressed in rat prostate and ovary Proceedings of the National Academy of Sciences USA 93 5925-5930

Kuiper GGJM, Carlsson B, Grandien K, Enmark E, Häggblad J, Nilsson S and Gustafsson J-Å (1997) Comparison of the ligand binding specificity and transcript tissue distribution of estrogen receptors $\alpha$ and $\beta$ Endocrinology 138 863-870

Kumar V, Green S, Stack G, Berry M, Jin JR and Chambon P (1987) Functional domains of the human estrogen receptor Cell 51 941-951

Lautincik J, Kolodzieyski L, Elias V, Hyttel P, Osawa Y and Sirotkin A (1994) Immunocytochemical localization of aromatase in the ovary of superovulated cattle, pigs, and sheep Acta Veterinarian Scandanavia 35 185-191

Lei ZM, Mishra S, Zou W, Xu B, Foltz M, Li X and Rao ChV (2001) Targeted disruption of luteinizing hormone/human chorionic gonadotropin receptor gene Molecular Endocrinology 15 184-200

Lenhart JA, Downer BR, Bagnell CA (1998) Connexin 43 gap junction protein expression during follicular development in the porcine ovary Biology of Reproduction 58 583-590

Leung PCK and Armstrong DT (1980) Further evidence in support of a shortloop feedback action of estrogen on ovarian androgen production Life Sciences 27 415-420

Levin ER (1999) Cellular functions of the plasma membrane estrogen receptor Trends in Endocrinology and Metabolism $10374-377$

Lima PH, Hotchkiss JR and Blomquist $\mathbf{C H}$ (2000) Characterization of $3 \alpha-$, $3 \beta-$, and 17 $\beta$-hydroxysteroid oxidoreductase, $5 \alpha$-reductase, and aromatase activity in adult rabbit lung Endocrinology Annual Meeting, Toronto Abstract 1546

Lu B, Leygue E, Dotzlaw H, Murphy LJ and Murphy LC (2000) Functional characteristics of a novel estrogen receptor- $\beta$ isoform, estrogen receptorß2 Journal of Endocrinology 25 229-242

*Lubahn DB, Moyer JS, Golding TS, Couse JF, Korach KS and Smithies O (1993) Alteration of reproductive function but not prenatal sexual development after insertional disruption of the mouse estrogen receptor gene Proceedings of the National Academy of Sciences USA 9011 162-11 166

Manikkam M, Bao B, Rosenfeld CS, Yuan X, Salfen BE, Calder MD, Youngquist RS, Keisler DH, Lubahn DB and Garverick HA (1999) Expression of bovine estrogen receptor- $\beta$ (bER $\beta$ ) mRNA throughout the first follicular wave in the ovary and effect of $\mathrm{LH}$ infusion on bER $\beta$ mRNA expression of second wave follicles Society for the Study of Reproduction Annual Meeting, Pullman, WA Abstract 52

Mayerhofer A and Garfield RE (1995) Immunocytochemical analysis of the expression of gap junction protein connexin 43 in the rat ovary Molecular Reproduction and Development 41 331-338

Melner MH and Korach KS (2000) A new database for tissue-specific gene expression and function in the ovary Endocrinology 1413051

Merk FB, Botticelli CR and Albright JT (1972) An intracellular response to estrogen by granulosa cells in the rat ovary; an electron microscopic study Endocrinology 99 992-1007

Metzger D and Chambon P (2001) Site- and time-specific gene targeting in the mouse Methods 24 71-80

Moore JT, McKee DD, Slentz-Kesler K, Moore LB, Jones SA, Horne EL, Su JL, Kliewer SA, Lehmann JM and Willson TM (1998) Cloning and characterization of human estrogen receptor beta isoforms Biochemical Biophysical Research Communications 247 75-78 
Morley P, Whitfield JF, Vanderhyden BC, Tsang BK and Schwartz JL (1992) A new, nongenomic estrogen action: the rapid release of intracellular calcium Endocrinology 131 1305-1312

Mosselman S, Polman J and Dijkema R (1996) ERß: identification and characterization of a novel human estrogen receptor FEBS Letters 392 49-53

Muskhelishivili L, Thompson PA, Kusewitt DF, Wang C and Kadlubar FF (2001) In situ hybridization and immunohistochemical analysis of cytochrome P450 1B1 expression in human normal tissues Journal of Histochemistry and Cytochemistry 49 229-236

Nadal A, Ropero AB, Laribi O, Maillet M, Fuentes E and Soria B (2000) Nongenomic actions of estrogens and xenoestrogens by binding at a plasma membrane receptor unrelated to estrogen receptor alpha and estrogen receptor beta Proceedings of the National Academy of Sciences USA $9711603-11608$

Nakano R, Nakayama T and Iwao M (1982) Inhibition of ovarian follicle growth by a chemical antiestrogen Hormone Research 16 230-236

Nakayama T, Nakano R and Iwao M (1981) Evidence for a role of endogenous estrogen on follicular growth in immature female rats Endocrinology Japan 28 715-723

Nayudu PL and Osborn SM (1992) Factors influencing the rate of preantral and antral growth of mouse ovarian follicles in vitro. Journal of Reproduction and Fertility 95 349-362

Nuttinck F, Peynot N, Humblot P, Massip A, Dessy F and Flechon JE (2000) Comparative immunohistochemical distribution of connexin 37 and connexin 43 throughout folliculogenesis in the bovine ovary Molecular Reproduction Development 57 60-66

O'Brien ML, Park K, In Y and Park-Sarge OK (1999) Characterization of estrogen receptor- $\beta$ (ER $\beta$ ) messenger ribonucleic acid and protein expression in rat granulosa cells Endocrinology 140 4530-4541

Parker MG (1995) Structure and function of estrogen receptors Vitamins Hormones 51 267-287

Peitras RJ and Szego CM (1999) Cell membrane estrogen receptors resurface Nature Medicine 5 1130-1131

Pelltier G and El-Alfy M (2000) Immunocytochemical localization of estrogen receptors $\alpha$ and $\beta$ in the human reproductive organs Journal of Endocrinology and Metabolism 85 4835-4840

Pelletier G, Labrie C and Labrie F (2000) Localization of oestrogen receptor $\alpha$, oestrogen receptor $\beta$ and androgen receptors in the rat reproductive organs Journal of Endocrinology 165 359-370

Petersen DN, Tkalcevic GT, Koza-Taylor PH, Turi TG and Brown TA (1997) Identification of estrogen receptor $\beta 2$, a functional variant of estrogen receptor $\beta$ expressed in normal rat tissues Endocrinology 139 1082-1092

Poola I, Koduri S, Chatra S and Clarke R (2000) Identification of twenty alternatively spliced estrogen receptor $\alpha$ mRNAs in breast cancer cell lines and tumors using splice targeted primer approach Journal of Steroid Biochemistry and Molecular Biology 72 249-258

Rey JM, Pujol P, Callier P, Cavailles V, Freiss G, Maudelonde T and Brouillet JP (2000) Semiquantitative reverse transcription-polymerase chain reaction to evaluate the expression patterns of genes involved in the oestrogen pathway Journal of Molecular Endocrinology 24 433-440

Richards JS, Ireland JJ, Rao MC, Bernath GA, Midgley AR, Jr and Reichert LE, Jr (1976) Ovarian follicular development in the rat: hormone receptor regulation by estradiol, follicle stimulating hormone, and luteinizing hormone Endocrinology 99 1562-1570

Richards JS, Jonassen JA, Rolfes AI, Kersey K and Reichert LE, Jr (1979) Adenosine 3',5'-monophosphate, luteinizing hormone receptor, and progesterone during granulosa cell differentiation: effects of estradiol and follicle stimulating hormone Endocrinology 104 765-773

Rissman EF, Wersinger SR, Taylor JA and Lubahn DB (1997) Estrogen receptor function as revealed by knockout studies: neuroendrocrine and behavioral aspects Hormones and Behavior 31 232-243

Roberts AJ and Skinner MK (1990) Estrogen regulation of theca cell steroidogenesis and differentiation: thecal cell-granulosa cell interactions Endocrinology 127 2918-2929

Robson JM (1937) Maintenance by oestrin of the luteal function in hypophysectomized rabbits Journal of Physiology 90 435-439

Rosenberg-Zand RS, Diamandis EP and Stanczyk FZ (2000) Hermaphrodiol may contribute significantly to the estrogenic/androgenic hormonal milieu of breast and prostrate cancer cells Endocrinology Annual Meeting, Toronto Abstract 773

Rosenfeld CS, Yuan X, Manikkam M, Calder MD, Garverick HA and Lubahn DB (1999) Cloning, sequencing, and localization of bovine estrogen receptor- $\beta$ within the ovarian follicle Biology of Reproduction 60 691-697

*Rosenfeld CS, Murray AA, Simmer G, Hufford MG, Smith MF, Spears N and Lubahn DB (2000) Gonadotropin induction of ovulation and corpus luteum formation in young estrogen receptor- $\alpha$ knockout mice Biology of Reproduction 62 599-605

*Rosenfeld CS, Roberts RM and Lubahn DB (2001) Estrogen receptor- and aromatase-deficient mice provide insight into the roles of estrogen in the ovary and uterus Molecular Reproduction and Development 59 336-346

Sar $\mathbf{M}$ and Welsch F (1999) Differential expression of estrogen receptor- $\beta$ and estrogen receptor- $\alpha$ in the rat ovary Endocrinology 140 963-971

Saunders PTK, Millar MR, Williams K, Macpherson S, Harkiss D, Anderson RA, Orr B, Groome NP, Scobie G and Fraser HM (2000) Differential expression of estrogen receptor $\alpha$ and $-\beta$ and androgen receptor in the ovaries of marmosets and humans Biology of Reproduction 63 1098-1105

Sauve F, McBroom LD, Gallant J, Moraitis AN, Labrie F and Giguere V (2001) CIA, a novel estrogen receptor coactivator with a bifunctional nuclear receptor interacting determinant Molecular Cellular Biology 21 343-353

Schomberg DW, Couse JF, Mukherjee A, Lubahn DB, Sar M, Mayo KE and Korach KS (1999) Targeted disruption of the estrogen receptor- $\alpha$ gene in female mice: characterization of ovarian responses and phenotype in the adult Endocrinology 140 2733-2744

Sharma SC, Clemens JW, Pisarska MD and Richards JS (1999) Expression and function of estrogen receptor subtypes in granulosa cells: regulation by estradiol and forskolin Endocrinology 140 4320-4334

Shores EM and Hunter MG (1999) Immunohistochemical localization of steroidogenic enzymes and comparison with hormone production during follicle development in the pig Reproduction Fertility and Development 11 337-344

Simoncini T, Hafezi-Moghadam A, Brazil DP, Ley K, Chin WW and Liao JK (2000) Interaction of oestrogen receptor with the regulatory subunit of phosphatidylinositol-3-OH kinase Nature 407 538-541

Smith GW, Gentry PC, Kong DK, Bao B, Roberts RM and Smith MF (1995) Expression of progesterone receptor mRNA within ovine post-surge follicles and corpora lutea 28th Annual Meeting of the Society for the Study of Reproduction, Davis, CA Abstract 380

Spears N, Murray AA, Allison V, Boland NI and Gosden RG (1998) Role of gonadotrophins and ovarian steroids in the development of mouse follicles in vitro. Journal of Reproduction and Fertility 113 19-26

Spicer LJ and Hammond JM (1987) Catecholestrogens stimulate progestin secretion by cultured porcine granulosa cells Molecular and Cellular Endocrinology 50 139-147

Taylor AH and Al-Azzawi F (2000) Immunolocalisation of oestrogen receptor $\beta$ in human tissues Journal of Molecular Endocrinology 24 145-155

Tekpetey FR and Armstrong DT (1994) Catecholestrogen modulation of steroid production by rat luteal cells: mechanism of action Molecular and Cellular Endocrinology 101 49-57

Telleria CM, Zhong L, Deb S, Srivastava RK, Park KS, Sugino N, Park-Sarge OK and Gibori G (1998) Differential expression of the estrogen receptors $\alpha$ and $\beta$ in the rat corpus luteum of pregnancy: regulation by prolactin and placental lactogens Endocrinology $1392432-2442$

Toda K, Takeda K, Okada T, Akira S, Saibara T, Kaname T, Yamamura K, Onishi S and Shizuta Y Targeting disruption of the aromatase P450 gene (Cyp19) in mice and their ovarian and uterine responses to $17 \beta$ oestradiol Journal of Endocrinology (in press)

Tremblay GB, Kunath T, Bergeron D, Lapointe L, Champigny C, Bader JA, Rossant J and Giguere V (2001) Diethylstilbestrol regulates trophoblas stem cell differentiation as a ligand of orphan nuclear receptor ERR $\beta$ Genes and Development 15 833-838

Welsh TH, Jr, Zhuang L-Z and Hsueh AJW (1983) Estrogen augmentation of gonadotropin-stimulated progestin biosynthesis in cultured rat granulosa cells Endocrinology 112 1916-1924 
Welshons WV, Lieberman ME and Gorski J (1984) Nuclear localization of unoccupied oestrogen receptors Nature 307 747-749

*White R and Parker MG (1998) Molecular mechanisms of steroid hormone action Endocrine Related Cancer 5 1-14

Yamashita S (1998) Localization and functions of steroid hormone receptors Histological Histopathology 13 255-270

Youngblood GL, Nesbitt $\mathbf{M N}$ and Payne AH (1989) The structural genes encoding P450scc and P450arom are closely linked on mouse chromosome 9 Endocrinology 125 2784-2786
Yu W, Dahl G and Werner R (1994) The connexin43 gene is responsive to oestrogen Proceedings of the Royal Society of London B Biological Sciences 22 125-132

Zhu BT and Conney AH (1998) Functional role of estrogen metabolism in target cells - review and perspectives Carcinogenesis 19 1-27

Zieba D, Bilinska B, Schmalz-Fraczek B and Murawski M (2000) Immunohistochemical localization of estrogen receptors in the ovine corpus luteum throughout the estrous cycle Folia Histochemistry Cytobiology 38 111-117 